\title{
TESHDISAL DIOTES
}

\section{Effects of Fire and Mechanical Treatment on Cercocarpus montanus and Ribes cereum}

\section{LEWIS YOUNG AND JAMES A. BAILEY}

Highlight: Effects of fire and of clipping stems at ground level on the quantity and quality of production (current annual growth) of true mountainmahogany (Cercocarpus montanus Raf.) and squaw currant (Ribes cereum Dougl.) were studied. For both plant species, treatments applied during the dormant season, and especially fire treatments, were more effective in increasing production than were treatments during the growing season. Dormant season burning increased production by 200 to $900 \%$ for at least 2 years. As production increased due to treatment effects, the concentrations of crude protein, phosphorus, and calcium decreased slightly in current annual growth of squaw currant. Similar, but nonsignificant trends were noted for crude protein and phosphorus in current annual growth of true mountainmahogany.

Browse constitutes an important, often critical portion of the winter diet of several wild ungulate species in the United States. Browse stands may lose their value to ungulates because (1) plant succession changes species composition, (2) stems grow out of reach of animals, or (3) plants become decadent and decline in productivity. Fire, mechanical manipulation, and herbicides are methods most used to rejuvenate browse stands. This study was designed to explore several factors affecting shrub responses to disturbance and to estimate among-plant variation in response to treatments. It was intended to serve as a basis for designing more intensive studies. Emphasis was therefore on testing many treatment combinations rather than on large sample sizes within treatments. However, since results indicate potential for managing two shrub species about which little is known, we are reporting them briefly, without review of literature which is contained in Young (1973).

True mountainmahogany (Cercocarpus montanus Raf.) is an important browse species in Colorado and has been studied somewhat. Squaw currant (Ribes cereum Dougl.) is less utilized but is also common in Colorado. The study was conducted at two sites in the eastern foothills of the Rocky Mountains in northcentral Colorado near Fort Collins. Site 1 was at 5,400 feet elevation; site 2 was at 7,000 feet.

Authors are graduate student and assistant professor of wildlife biology, respectively, Colorado State University, Fort Collins. At present, Young is soil scientist, U.S. Department of Agriculture, Santa present, Young is soil scientist, U.S. Depart

This report is from a thesis submitted to the Graduate Faculty of Colorado State University in partial fulfillment of the requirements for the degree of Master of Science. Collection of 1972 data by William Reneau, Steve Brock, and Fred Provenza is gratefully acknowledged.

Manuscript received July 8, 1974.

\section{Design and Methods}

Treatments were arranged for factorial analysis with: two study sites, two plant species, two seasons of treatment (dormant-late winter or March, 1971; and growing-height of blooming stage or May and early June, 1971), three treatments (control, fire, and clipping), and two intensities of both fire and clipping treatments. Plants were treated in both seasons at one site but only in the growing season at the other. Each treatment category was replicated on five randomly selected shrubs so that 75 plants of each species were studied.

Fire treatments were applied to plants individually with a kerosene-burning flame gun. For the high-intensity treatment, the flame was applied to the plant until the bark glowed red.

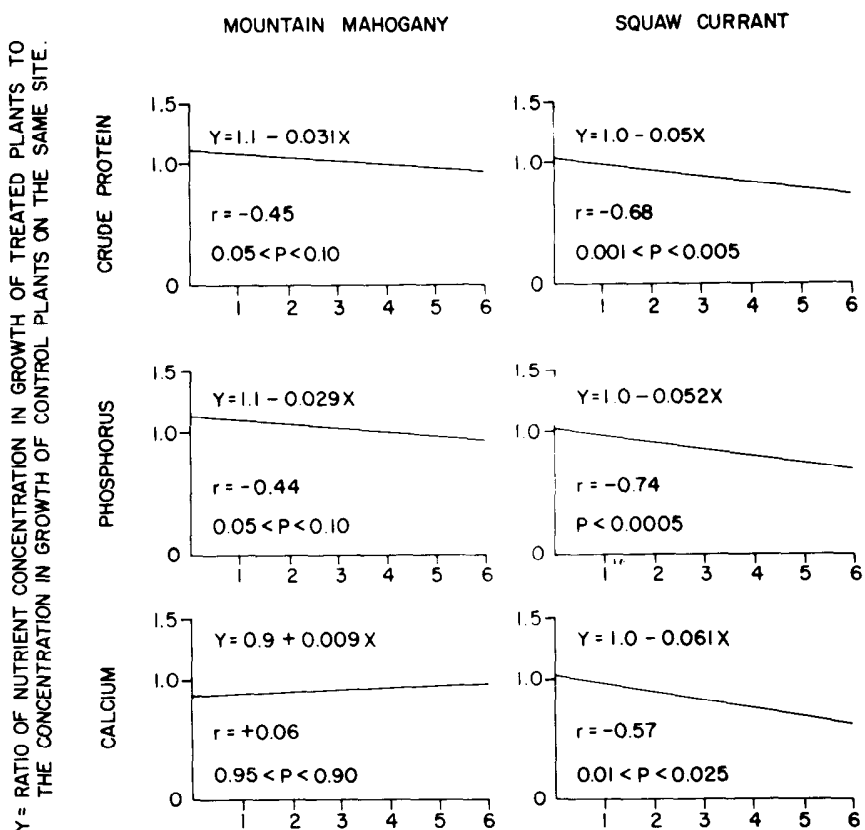

$X=$ RATIO OF PRODUCTION BY TREATED PLANTS TO PRODUCTION BY CONTROL PLANTS ON THE SAME SITE.

Fig. 1. Relationship between change in current annual growth production following shrub treatment and concentrations of crude protein, calcium, and phosphorus in current annual growth of mountainmahogany and squaw currant. 
Table 1. Mean first year (1971) and second year (1972) production of current annual growth for five mountainmahogany plants in each treatment.

\begin{tabular}{|c|c|c|c|c|c|c|}
\hline \multirow[b]{3}{*}{ Treatment } & \multirow{2}{*}{\multicolumn{2}{|c|}{$\frac{\text { Site } 1}{\text { Growing-season treatment }}$}} & \multicolumn{4}{|c|}{ Site 2} \\
\hline & & & \multicolumn{2}{|c|}{ Growing-season treatment } & \multicolumn{2}{|c|}{ Dormant-season treatment } \\
\hline & 1971 & 1972 & 1971 & 1972 & 1971 & 1972 \\
\hline Control (g/plant) & 62.9 & 37.2 & $6.1^{2}$ & $2.5^{2}$ & $6.1^{2}$ & $2.5^{2}$ \\
\hline \multicolumn{7}{|l|}{ Fire } \\
\hline High-intensity (ratio) ${ }^{1}$ & 0.6 & 1.1 & 0.6 & 1.0 & 4.8 & 4.6 \\
\hline Low-intensity (ratio) ${ }^{1}$ & 0.7 & 1.8 & 1.0 & 1.7 & 6.5 & 9.1 \\
\hline \multicolumn{7}{|l|}{ Clipping } \\
\hline High-intensity (ratio) ${ }^{1}$ & 1.3 & 2.0 & 0.5 & 0.4 & 1.8 & 1.8 \\
\hline Low-intensity (ratio) ${ }^{1}$ & 0.7 & 1.1 & 0.7 & 1.3 & 3.6 & 1.6 \\
\hline
\end{tabular}

1Production by treated plants is expressed as a ratio to production by control plants in the same year-site class.

${ }^{2}$ Average of ten control plants; five from growing-season series and five from dormant-season series.

The entire plant was treated. For the low-intensity fire treatment, each part of the plant was treated for approximately 1 second. Eighty and $40 \%$ of the stems arising from the root collar of each plant were severed $5 \mathrm{~cm}$ above ground level for the high- and low-intensity clipping treatments, respectively.

Production by the shrubs was estimated during winters following the 1971 and 1972 growing seasons using an average twig-weight method similar to that of Schaefer (1963). Only sprouts or twigs longer than $1 \mathrm{~cm}$ were considered. A sprout is defined as a unit of current annual growth originating directly from the root crown of a plant or in the case of the clipping treatment originating from either the root crown or the remaining $5 \mathrm{~cm}$ of a severed stem. A twig is a unit of growth originating from older growth on a stem except as a sprout is defined on severed stems. From each shrub, samples of newly grown sprouts and twigs were collected, dried at $60^{\circ} \mathrm{C}$ for 48 hours, and weighed. Mean weights per sprout and per twig were calculated, then multiplied by the numbers of sprouts and twigs, respectively, on the shrub to obtain the estimated production.

Samples of 1971 growth, collected in February and March, 1972, were analyzed for crude protein using the micro-Kjeldahl method of the Department of Animal Science, Colorado State University. Samples were also analyzed for phosphorus and calcium using the Association of Official Analytical Chemists method (Horwitz, 1970).

Data from the 1971 growing season were analyzed by the Statistical Laboratory, Colorado State University. The 0.05 significance level was used in declaring significant differences between means.

\section{Results and Discussion}

All plants survived the first growing season after treatment. Two plants died the second growing season, for a survival rate of $98 \%$. Both these plants were squaw currant that had been burned during the growing season.

Treatments applied during the dormant season resulted in significantly greater production than did treatments applied during the growing season (Tables 1,2 ). This was true of both plant species and was supported by second-year data.

Fire treatments applied during the dormant season were most effective in increasing production of mountainmahogany (Table 1). For dormant-season treatment of squaw currant, fire treatments showed little or no advantage over clipping treatments (Table 2).

Fire treatments applied during the growing season were detrimental to production for both plant species the first year (Tables 1,2). Decreased production was still evident in squaw currant the second year, although mountainmahogany appeared to have recovered. Of treatments applied during the growing season, only clipping treatments on squaw currant showed any promise for increasing production (Tables 1, 2).

While production by control plants was greater at Site 1 than at Site 2 (Tables 1, 2) there were no significant differences between sites in the responses of shrubs to growing-season treatments.

To aid in designing future similar experiments, it is noted that the coefficient of variation of production among plants treated alike was $85 \%$ of mean production for squaw currant and $80 \%$ of mean production for mountainmahogany.

Mean crude protein concentrations were significantly greater in current annual growth of mountainmahogany $(8.0 \%)$ than in squaw currant (5.6\%). Mean concentrations of phosphorus and calcium were significantly greater in current annual growth of squaw currant $(\mathrm{P}, 0.23 \% ; \mathrm{Ca}, 0.85 \%)$ than in mountainmahogany (P, $0.20 \% ; \mathrm{Ca}, 0.39 \%)$.

With squaw currant, crude protein, phosphorus, and calcium concentrations in current annual growth decreased slightly but significantly as production increased due to

Table 2. Mean first year (1971) and second year (1972) production of current annual growth for five squaw currant plants in each treatment.

\begin{tabular}{|c|c|c|c|c|c|c|}
\hline \multirow[b]{3}{*}{ Treatment } & \multirow{2}{*}{\multicolumn{2}{|c|}{$\frac{\text { Site } 1}{\text { Growing-season treatment }}$}} & \multicolumn{4}{|c|}{ Site 2} \\
\hline & & & \multicolumn{2}{|c|}{ Growing-season treatment } & \multicolumn{2}{|c|}{ Dormant-season treatmen } \\
\hline & 1971 & 1972 & 1971 & 1972 & 1971 & 1972 \\
\hline Control (g/plant) & 36.8 & 42.2 & $10.8^{2}$ & $7.6^{2}$ & $10.8^{2}$ & $7.6^{2}$ \\
\hline $\begin{array}{l}\text { Fire } \\
\begin{array}{l}\text { High-intensity (ratio) } \\
\text { Low-intensity (ratio) }\end{array}\end{array}$ & $\begin{array}{l}0.5 \\
0.5\end{array}$ & $\begin{array}{l}0.5 \\
0.7\end{array}$ & $\begin{array}{l}1.3 \\
0.4\end{array}$ & $\begin{array}{l}1.5 \\
0.3\end{array}$ & $\begin{array}{l}3.2 \\
5.2\end{array}$ & $\begin{array}{l}2.6 \\
2.1\end{array}$ \\
\hline $\begin{array}{l}\text { Clipping } \\
\text { High-intensity (ratio) } \\
\text { Low-intensity (ratio) }^{1}\end{array}$ & $\begin{array}{l}2.4 \\
2.7\end{array}$ & $\begin{array}{l}1.7 \\
1.3\end{array}$ & $\begin{array}{l}3.1 \\
2.0\end{array}$ & $\begin{array}{l}4.0 \\
1.4 \\
\end{array}$ & $\begin{array}{l}3.7 \\
2.0\end{array}$ & $\begin{array}{l}2.6 \\
2.0\end{array}$ \\
\hline
\end{tabular}

\footnotetext{
${ }_{1}$ Production by treated plants is expressed as a ratio to production by control plants in the same year-site class.

${ }^{2}$ Average of ten control plants; five from growing-season series and five from dormant-season series.
} 
treatment effects (Fig. 1). With mountainmahogany, crude protein and phosphorus concentrations also tended to decrease as production increased, whereas calcium levels appeared unrelated to changes in production.

The importance of relatively small changes in chemical composition as production varies is unknown. More important, these results show from 200 to $900 \%$ increase in browse production for at least 2 years after shrub treatment during the dormant season. This suggests great potential for management of big game winter ranges on public lands to compensate for loss of winter ranges due to expanding human activities on private and public land in the Rocky Mountain Region.

\section{Literature Cited}

Horwitz, W. (ed.) 1970. Official methods of analysis. 11th ed. Association of Official Analytical Chemists. Washington, D.C. $1015 \mathrm{p}$.

Schacfer, E. L., Jr. 1963. The twig-count method for measuring hardwood deer browse. J. Wildl. Ma nage. 27:428-437.

Young, D. L. 1973. First-year effects of fire, clipping, and herbicide on the quantity and quality of current annual growth of two species of shrubs. MS Thesis. Colorado State Univ. 78 p.

\section{ㅁㅁㅁㅁ}

